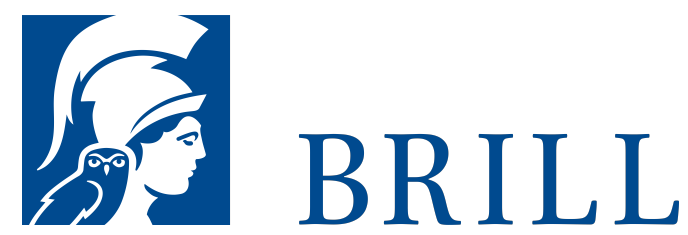

\title{
Das Archiv der Taricheuten Amenneus und Onnophris aus Tanis (P.Tarich)
}

\section{Author: Charikleia Armoni}

Die Nordrhein-Westfälische Akademie der Wissenschaften und der Künste ist eine Vereinigung der führenden Forscherinnen und Forscher des Landes. Sie wurde 1970 als Nachfolgeeinrichtung der Arbeitsgemeinschaft für Forschung des Landes Nordrhein-Westfalen gegründet. Die Akademie ist in drei wissenschaftliche Klassen für Geisteswissenschaften, für Naturwissenschaften und Medizin sowie für Ingenieur- und Wirtschaftswissenschaften und in eine Klasse der Künste gegliedert.

Mit Publikationen zu den wissenschaftlichen Vorträgen in den Klassensitzungen, zu öffentlichen Veranstaltungen und Symposien will die Akademie die Fach- und allgemeine Öffentlichkeit über die Arbeiten der Akademie und ihrer Forschungsstellen informieren.

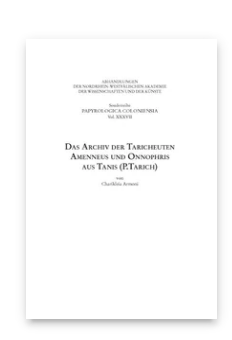

Pages: VIII + 168 Seiten, $18 \mathrm{~s} / \mathrm{w}$ Abb.

Language:

German

Subjects:

Ancient History, Classical Studies

Publisher: Brill | Schöningh

Series:

Sonderreihe der Abhandlungen

Papyrologica

Coloniensia,

Volume: 37

E-Book (PDF)

Released online: 22 Jun 2020

ISBN: 978-3-

657-77934-5

List price

Paperback

Publication date: og Dec 2013

ISBN: 978-35o6-77934-2 List price 
For more information see brill.com

Order information: Order online at brill.com +44330 333 0049 | customerservices@brill.com Submission information: brill.com/authors

Titles published by Brill | Fink, Brill | mentis or Brill | Schöningh: +49(o)715413279216| brill@brocom.de 